\title{
molecules
}

ISSN 1420-3049

www.mdpi.com/journal/molecules

Article

\section{Cytotoxic Oleanane-Type Triterpenoid Saponins from the Rhizomes of Anemone rivularis var. flore-minore}

\author{
Xiaoyang Wang ${ }^{1,2}$, Minchang Wang ${ }^{3}$, Min Xu ${ }^{3}$, Yi Wang ${ }^{4}$, Haifeng Tang ${ }^{1,4, *}$ \\ and Xiaoli Sun ${ }^{1,2, *}$
}

1 Department of Pharmacy, Xijing Hospital, Fourth Military Medical University, Xi'an 710032, China; E-Mail: steveplum@sina.com

2 Department of Chemistry, School of Pharmacy, Fourth Military Medical University, Xi'an 710032, China

3 Nuclear Magnetic Resonance Center, Xi'an Modern Chemistry Research Institute, Xi'an 710065, China; E-Mails:wmc204@163.com (M.W.); naturemin2001@163.com (M.X.)

4 Institute of Materia Medica, School of Pharmacy, Fourth Military Medical University, Xi'an 710032, China; E-Mail: yiwang821203@126.com

* Authors to whom correspondence should be addressed; E-Mails: tanghaifeng71@163.com (H.T.); xiaolis@fmmu.edu.cn (X.S.); Tel./Fax: +86-29-8477-4748 (H.T.); Tel./Fax: +86-29-8477-2471 (X.S.).

Received: 20 January 2014; in revised form: 6 February 2014 / Accepted: 10 February 2014 / Published: 18 February 2014

\begin{abstract}
Phytochemical investigation of the $n$-BuOH extract of the rhizomes of Anemone rivularis var. flore-minore led to the isolation of five new oleanane-type triterpenoid saponins 1-5, together with five known saponins 6-10. Their structures were determined by the extensive use of 1D and 2D NMR experiments, along with ESIMS analyses and acid hydrolysis. The aglycone of $\mathbf{4}$ and $\mathbf{5}$ was determined as $21 \alpha$-hydroxyoleanolic acid, which was reported in this genus for the first time. The cytotoxicity of these compounds was evaluated against four human cancer cell line, including HL-60 (promyelocytic leukemia), HepG2 (hepatocellular carcinoma), A549 (lung carcinoma) and HeLa (cervical carcinoma). The monodesmosidic saponins 6-8 exhibited cytotoxic activity toward all tested cancer cell lines, with $\mathrm{IC}_{50}$ values in the $7.25-22.38 \mu \mathrm{M}$ range.
\end{abstract}

Keywords: Anemone rivularis var. flore-minore; triterpenoid saponin; cytotoxicity 


\section{Introduction}

The genus Anemone (Ranunculaceae) consists of about 150 species with a nearly global distribution, of which about 50 species are found in China. More than 10 species of this genus have been used as Chinese folk medicines for a long time. For example, the rhizome of $A$. raddeana, named "Liangtoujian", is recorded in the Chinese Pharmacopeia for the treatment of rheumatism and neuralgia [1]. Extensive phytochemical and pharmacological studies on this genus have proved the triterpenoid saponins to be the main bioactive substances, with potentially useful biological properties including antitumor, antibacterial, antiperoxidation, insect deterrence, etc. [2-9]. Anemone rivularis var. flore-minore is distributed mainly in the Tsinling Mountains in Shaanxi Province of China. The whole plants of this species are also used as a folk medicine named "Poniuqi" for the treatment of hepatitis, muscle and joint pain, emission, stranguria, edema, etc. [10].

Our previous phytochemical investigations of the whole plants of this species resulted in the isolation of a new gypsogenin saponin, a new diterpene glycoside, a new lignanoid glycoside, as well as a series of oleanane-type triterpenoid saponins [11,12]. As part of our ongoing search for new bioactive natural compounds from this genus [11-16], the present study of the rhizomes of $A$. rivularis var. flore-minore led to the isolation of five new oleanane-type saponins $\mathbf{1 - 5}$, along with five known saponins 6-10 (Figure 1). Herein, we report the isolation and structural elucidation of these saponins, along with their cytotoxic activities against four human cancer cell lines, promyelocytic leukemia HL-60, hepatocellular liver carcinoma HepG2, lung carcinoma A549 and cervical carcinoma HeLa.

Figure 1. Structures of compounds 1-10.
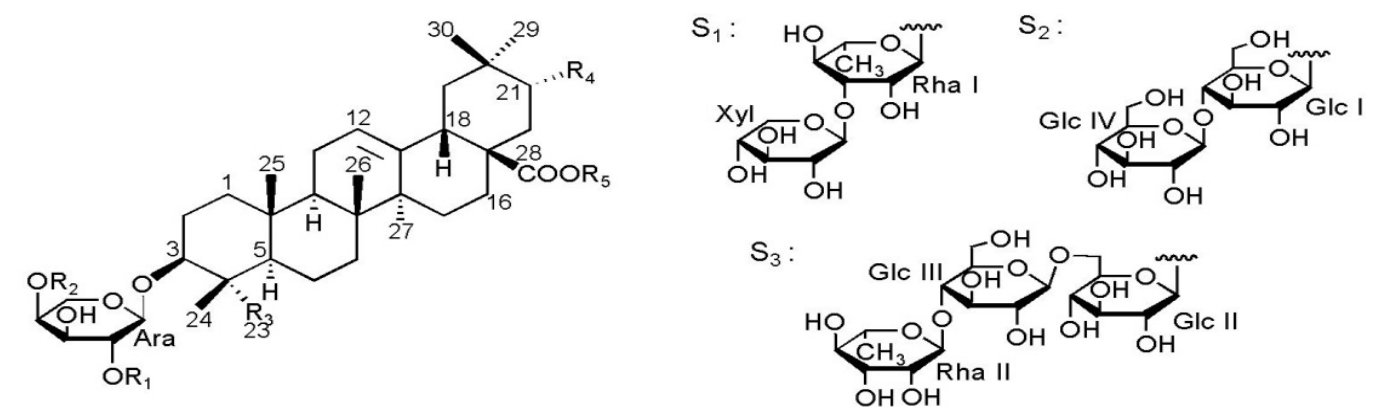

$\begin{array}{ccccccccccc} & \mathbf{1} & \mathbf{2} & \mathbf{3} & \mathbf{4} & \mathbf{5} & \mathbf{6} & \mathbf{7} & \mathbf{8} & \mathbf{9} & \mathbf{1 0} \\ \mathbf{R}_{\mathbf{1}} & \mathrm{S}_{1} & \mathrm{~S}_{1} & \mathrm{~S}_{1} & \mathrm{Rha} \mathrm{I} & \mathrm{Rhal} & \mathrm{S}_{1} & \mathrm{Rha} \mathrm{I} & \mathrm{S}_{1} & \mathrm{~S}_{1} & \mathrm{H} \\ \mathbf{R}_{\mathbf{2}} & \mathrm{Glcl} & \mathrm{Glcl} & \mathrm{S}_{2} & \mathrm{Glcl} & \mathrm{S}_{2} & \mathrm{H} & \mathrm{Glc} \mathrm{I} & \mathrm{Glc} \mathrm{I} & \mathrm{H} & \mathrm{H} \\ \mathbf{R}_{3} & \mathrm{CHO} & \mathrm{CHO} & \mathrm{CH}_{3} & \mathrm{CH}_{3} & \mathrm{CH}_{3} & \mathrm{CH}_{2} \mathrm{OH} & \mathrm{CH}_{2} \mathrm{OH} & \mathrm{CH}_{3} & \mathrm{CH}_{3} & \mathrm{CHO} \\ \mathbf{R}_{\mathbf{4}} & \mathrm{H} & \mathrm{H} & \mathrm{H} & \mathrm{OH} & \mathrm{OH} & \mathrm{H} & \mathrm{H} & \mathrm{H} & \mathrm{H} & \mathrm{H} \\ \mathbf{R}_{\mathbf{5}} & \mathrm{Glc} \mathrm{II} & \mathrm{S}_{3} & \mathrm{Glc} \mathrm{II} & \mathrm{S}_{3} & \mathrm{~S}_{3} & \mathrm{H} & \mathrm{H} & \mathrm{H} & \mathrm{S}_{3} & \mathrm{~S}_{3}\end{array}$

\section{Results and Discussion}

Compound 1 was obtained as a white amorphous powder and showed positive results to the Liebermann-Burchard and Molisch tests. The molecular formula $\mathrm{C}_{58} \mathrm{H}_{92} \mathrm{O}_{26}$ was deduced from the $[\mathrm{M}+\mathrm{Na}]^{+}$ion at $m / z=1,227.5779$ (calcd. for $\mathrm{C}_{58} \mathrm{H}_{92} \mathrm{O}_{26} \mathrm{Na}^{+}, 1,227.5775$ ) in the positive ion mode HRESIMS. 
Table 1. ${ }^{1} \mathrm{H}-(500 \mathrm{MHz})$ and ${ }^{13} \mathrm{C}-\mathrm{NMR}(125 \mathrm{MHz})$ chemical shifts assignments for the aglycone moieties of compounds $\mathbf{1}-\mathbf{5}$ in pyridine- $d_{5}$.

\begin{tabular}{|c|c|c|c|c|c|c|c|c|c|c|}
\hline \multirow{2}{*}{$\mathbf{C}$} & \multicolumn{2}{|r|}{1} & \multicolumn{2}{|r|}{2} & \multicolumn{2}{|r|}{3} & \multicolumn{2}{|r|}{4} & \multicolumn{2}{|r|}{5} \\
\hline & $\delta_{\mathrm{C}}$ & $\delta_{\mathrm{H}}(m, J \mathrm{~Hz})$ & $\delta_{\mathrm{C}}$ & $\delta_{\mathrm{H}}(m, J \mathrm{~Hz})$ & $\delta_{\mathrm{C}}$ & $\delta_{\mathrm{H}}(m, J \mathrm{~Hz})$ & $\delta_{\mathrm{C}}$ & $\delta_{\mathrm{H}}(m, J \mathbf{H z})$ & $\delta_{\mathrm{C}}$ & $\delta_{\mathrm{H}}(m, J \mathbf{H z})$ \\
\hline 1 & 38.2 & $0.98,1.56 \mathrm{~m}$ & 38.3 & $1.00,1.60 \mathrm{~m}$ & 38.8 & $1.44,0.88 \mathrm{~m}$ & 38.9 & $0.92,1.46 \mathrm{~m}$ & 39.0 & $0.95,1.48 \mathrm{~m}$ \\
\hline 2 & 25.5 & $1.85,2.09 \mathrm{~m}$ & 25.5 & $1.89,2.09 \mathrm{~m}$ & 26.7 & $2.02,1.81 \mathrm{~m}$ & 26.7 & $1.85,2.06 \mathrm{~m}$ & 26.7 & $1.88,2.10 \mathrm{~m}$ \\
\hline 3 & 81.6 & $4.05 \mathrm{~m}$ & 81.7 & $4.08 \mathrm{~m}$ & 88.6 & $\begin{array}{c}3.23 \mathrm{dd} \\
(4.0,11.6)\end{array}$ & 88.7 & $\begin{array}{c}3.27 \mathrm{dd} \\
(3.9,11.6)\end{array}$ & 88.7 & $\begin{array}{c}3.29 \mathrm{dd} \\
(3.8,11.6)\end{array}$ \\
\hline 4 & 55.5 & - & 55.7 & - & 39.5 & - & 39.5 & - & 39.5 & - \\
\hline 5 & 47.9 & $1.36 \mathrm{~m}$ & 48.0 & $1.37 \mathrm{~m}$ & 56.0 & $0.75 \mathrm{~d}(11.5)$ & 56.0 & $0.78 \mathrm{~d}(11.5)$ & 56.0 & $0.79 \mathrm{~d}(11.5)$ \\
\hline 6 & 20.6 & $0.96,1.38 \mathrm{~m}$ & 20.6 & $0.98,1.42 \mathrm{~m}$ & 18.5 & $1.42,1.24 \mathrm{~m}$ & 18.5 & $1.25,1.43 \mathrm{~m}$ & 18.5 & $1.26,1.47 \mathrm{~m}$ \\
\hline 7 & 32.5 & $1.18,1.42 \mathrm{~m}$ & 32.5 & $1.19,1.42 \mathrm{~m}$ & 33.1 & $1.40,1.23 \mathrm{~m}$ & 33.1 & $1.24,1.40 \mathrm{~m}$ & 33.2 & $1.25,1.41 \mathrm{~m}$ \\
\hline 8 & 40.2 & - & 40.3 & - & 39.8 & - & 39.8 & - & 39.8 & - \\
\hline 9 & 48.2 & $1.68 \mathrm{~m}$ & 48.2 & $1.71 \mathrm{~m}$ & 48.0 & $1.60 \mathrm{~m}$ & 48.1 & $1.66 \mathrm{~m}$ & 48.1 & $1.67 \mathrm{~m}$ \\
\hline 10 & 36.3 & - & 36.3 & - & 37.0 & - & 37.0 & - & 37.1 & - \\
\hline 11 & 23.4 & $1.91,1.99 \mathrm{~m}$ & 23.5 & $1.90,2.02 \mathrm{~m}$ & 23.7 & $1.93,1.86 \mathrm{~m}$ & 23.7 & $1.87,1.93 \mathrm{~m}$ & 23.7 & $1.86,1.94 \mathrm{~m}$ \\
\hline 12 & 122.6 & 5.40 br s & 122.6 & 5.41 br s & 122.8 & 5.39 br s & 122.8 & 5.43 br s & 122.9 & 5.45 br s \\
\hline 13 & 144.1 & - & 144.2 & - & 144.1 & - & 144.2 & - & 144.3 & - \\
\hline 14 & 42.2 & - & 42.2 & - & 42.1 & - & 42.3 & - & 42.3 & - \\
\hline 15 & 28.3 & $1.14,2.03 \mathrm{~m}$ & 28.3 & $1.15,2.06 \mathrm{~m}$ & 28.3 & $2.27,1.14 \mathrm{~m}$ & 28.5 & $1.16,2.30 \mathrm{~m}$ & 28.6 & $1.18,2.30 \mathrm{~m}$ \\
\hline 16 & 23.4 & $1.76,2.01 \mathrm{~m}$ & 23.4 & $1.77,2.04 \mathrm{~m}$ & 23.4 & $2.05,1.91 \mathrm{~m}$ & 27.0 & $2.36,3.08 \mathrm{~m}$ & 27.0 & $2.33,3.10 \mathrm{~m}$ \\
\hline 17 & 47.1 & - & 47.2 & - & 46.9 & - & 47.3 & - & 47.3 & - \\
\hline 18 & 41.7 & $\begin{array}{c}3.13 \mathrm{dd} \\
(3.8,13.5)\end{array}$ & 41.7 & $\begin{array}{c}3.15 \mathrm{dd} \\
(3.9,13.5)\end{array}$ & 41.6 & $\begin{array}{c}3.16 \mathrm{dd} \\
(3.8,13.4)\end{array}$ & 41.7 & $\begin{array}{c}3.36 \mathrm{dd} \\
(3.2,14.0)\end{array}$ & 41.8 & $\begin{array}{c}3.35 \mathrm{dd} \\
(3.3,13.9)\end{array}$ \\
\hline 19 & 46.1 & $1.23,1.74 \mathrm{~m}$ & 46.1 & $1.23,1.75 \mathrm{~m}$ & 46.2 & $1.71,1.21 \mathrm{~m}$ & 41.3 & $1.71,1.20 \mathrm{~m}$ & 41.5 & $1.75,1.22 \mathrm{~m}$ \\
\hline 20 & 30.6 & - & 30.7 & - & 30.7 & - & 35.7 & - & 35.7 & - \\
\hline 21 & 33.9 & $1.11,1.34 \mathrm{~m}$ & 34.0 & $1.13,1.36 \mathrm{~m}$ & 33.9 & $1.30,1.08 \mathrm{~m}$ & 73.3 & 3.65 br s & 73.3 & 3.66 br s \\
\hline 22 & 32.5 & $1.72,1.89 \mathrm{~m}$ & 32.5 & $1.72,1.90 \mathrm{~m}$ & 32.5 & $1.82,1.74 \mathrm{~m}$ & 39.6 & $2.25,2.28 \mathrm{~m}$ & 39.7 & $2.23,2.29 \mathrm{~m}$ \\
\hline 23 & 206.3 & $9.61 \mathrm{~s}$ & 206.4 & $9.66 \mathrm{~s}$ & 28.1 & $1.30 \mathrm{~s}$ & 28.1 & $1.29 \mathrm{~s}$ & 28.2 & $1.31 \mathrm{~s}$ \\
\hline 24 & 10.5 & $1.32 \mathrm{~s}$ & 10.6 & $1.34 \mathrm{~s}$ & 17.2 & $1.15 \mathrm{~s}$ & 17.2 & $1.16 \mathrm{~s}$ & 17.2 & $1.17 \mathrm{~s}$ \\
\hline 25 & 15.6 & $0.89 \mathrm{~s}$ & 15.7 & $0.89 \mathrm{~s}$ & 15.5 & $0.83 \mathrm{~s}$ & 15.6 & $0.87 \mathrm{~s}$ & 15.7 & $0.88 \mathrm{~s}$ \\
\hline 26 & 17.5 & $1.05 \mathrm{~s}$ & 17.5 & $1.06 \mathrm{~s}$ & 17.4 & $1.06 \mathrm{~s}$ & 17.4 & $1.09 \mathrm{~s}$ & 17.4 & $1.10 \mathrm{~s}$ \\
\hline 27 & 26.2 & $1.21 \mathrm{~s}$ & 26.2 & $1.21 \mathrm{~s}$ & 26.1 & $1.23 \mathrm{~s}$ & 25.6 & $1.33 \mathrm{~s}$ & 25.7 & $1.35 \mathrm{~s}$ \\
\hline 28 & 176.6 & - & 176.5 & - & 176.5 & - & 176.5 & - & 176.5 & - \\
\hline 29 & 33.1 & $0.86 \mathrm{~s}$ & 33.1 & $0.86 \mathrm{~s}$ & 33.1 & $0.86 \mathrm{~s}$ & 28.3 & $1.14 \mathrm{~s}$ & 28.4 & $1.15 \mathrm{~s}$ \\
\hline 30 & 23.7 & $0.88 \mathrm{~s}$ & 23.7 & $0.87 \mathrm{~s}$ & 23.7 & $0.87 \mathrm{~s}$ & 24.9 & $1.00 \mathrm{~s}$ & 25.0 & $1.01 \mathrm{~s}$ \\
\hline
\end{tabular}

The analysis of the NMR data (Tables 1 and 2) indicated that 1 was a saponin containing one triterpene aglycone and five monosaccharides. The 1D-NMR spectra showed signals for six tertiary methyl groups at $\delta_{\mathrm{H}} 0.86\left(\mathrm{H}_{3}-29\right), 0.88\left(\mathrm{H}_{3}-30\right), 0.89\left(\mathrm{H}_{3}-25\right), 1.05\left(\mathrm{H}_{3}-25\right), 1.27\left(\mathrm{H}_{3}-27\right)$ and 1.32 $\left(\mathrm{H}_{3}-24\right)$, one olefinic proton signal at $\delta_{\mathrm{H}} 5.40(1 \mathrm{H}$, br s) with two typical olefinic carbon signals at $\delta_{\mathrm{C}} 122.6$ and 144.1, one aldehyde proton signal at $\delta_{\mathrm{H}} 9.61(1 \mathrm{H}, \mathrm{s})$ with the corresponding aldehyde carbon signal at $\delta_{\mathrm{C}} 206.3$, and one carbonyl signal at $\delta_{\mathrm{C}}$ 176.6, which revealed that the aglycone of 1 was an oleanolic acid derivative with one of the methyl groups substituted by an aldehyde function. The aldehyde function was located at C-23 on the basis of the downfield shift ( $+16.0 \mathrm{ppm})$ exhibited by 
$\mathrm{C}-4\left(\delta_{\mathrm{C}} 55.5\right)$ and the highfield shifts $(-7.0 \mathrm{ppm},-8.1 \mathrm{ppm},-6.7 \mathrm{ppm})$ exhibited, respectively, by C-3 $\left(\delta_{\mathrm{C}} 84.6\right), \mathrm{C}-5\left(\delta_{\mathrm{C}} 47.9\right)$ and $\mathrm{C}-24\left(\delta_{\mathrm{C}} 10.5\right)$ in comparison with the same carbon resonances in an oleanene skeleton bearing a Me-23 [16]. The correlations of $\mathrm{H}-23\left(\delta_{\mathrm{H}} 9.61\right)$ with $\mathrm{H}-3\left(\delta_{\mathrm{H}} 4.05\right)$ and $\mathrm{H}-5\left(\delta_{\mathrm{H}} 1.36\right)$ observed in the NOESY spectrum indicated the $\alpha$-configuration for the 23-CHO function (Figure 2). The HMBC spectrum of 1 also allowed to determine the position of the aldehyde function by showing the correlations between $\mathrm{H}-23\left(\delta_{\mathrm{H}} 9.61\right)$ and C-3 $\left(\delta_{\mathrm{C}} 84.6\right), \mathrm{C}-4\left(\delta_{\mathrm{C}} 55.5\right)$ and C-24 $\left(\delta_{\mathrm{C}} 10.5\right)$ (Figure 2$)$. The assignments of the NMR signals associated with the aglycone moiety were derived from ${ }^{1} \mathrm{H}-{ }^{1} \mathrm{H}$ COSY, TOCSY, HSQC, HMBC and NOESY experiments. These data revealed the aglycone of 1 was gypsogenin [17,18]. The ${ }^{13} \mathrm{C}-\mathrm{NMR}$ shifts of C-3 at $\delta_{\mathrm{C}} 81.6$ and C-28 at $\delta_{\mathrm{C}} 176.6$ implied that sugar linkages were at both $\mathrm{C}-3$ and C-28. The correlations of H-3 with $\mathrm{H}-23$ and H-5 observed in the NOESY spectrum indicated the $\beta$-configuration for the 3- $O$-sugar moiety (Figure 2).

Table 2. ${ }^{1} \mathrm{H}-(500 \mathrm{MHz})$ and ${ }^{13} \mathrm{C}-\mathrm{NMR}(125 \mathrm{MHz})$ chemical shifts assignments for the sugar moieties of compounds $\mathbf{1}-\mathbf{5}$ in pyridine- $d_{5}(\mathrm{~m}, J \mathrm{~Hz})$.

\begin{tabular}{|c|c|c|c|c|c|c|c|c|c|c|}
\hline \multirow{2}{*}{ C } & \multicolumn{2}{|r|}{1} & \multicolumn{2}{|r|}{2} & \multicolumn{2}{|r|}{3} & \multicolumn{2}{|r|}{4} & \multicolumn{2}{|r|}{5} \\
\hline & $\delta_{\mathrm{C}}$ & $\delta_{\mathrm{H}}$ & $\delta_{\mathrm{C}}$ & $\delta_{\mathrm{H}}$ & $\delta_{\mathrm{C}}$ & $\delta_{\mathrm{H}}$ & $\delta_{\mathrm{C}}$ & $\delta_{\mathrm{H}}$ & $\delta_{\mathrm{C}}$ & $\delta_{\mathrm{H}}$ \\
\hline \multicolumn{11}{|c|}{ 3-O-sugar (Confirm here) } \\
\hline \multicolumn{11}{|c|}{ Ara } \\
\hline 1 & 104.6 & $4.92 \mathrm{~d}(7.1)$ & 104.6 & $4.91 \mathrm{~d}(7.2)$ & 105.3 & $4.72 \mathrm{~d}(6.9)$ & 105.0 & $4.77 \mathrm{~d}(6.2)$ & 105.2 & $4.74 \mathrm{~d}(6.2)$ \\
\hline 2 & 75.6 & $4.48 \mathrm{~m}$ & 75.5 & $4.50 \mathrm{~m}$ & 75.5 & $4.50 \mathrm{~m}$ & 76.4 & $4.50 \mathrm{~m}$ & 76.1 & $4.49 \mathrm{~m}$ \\
\hline 3 & 75.5 & $3.91 \mathrm{~d}(10.3)$ & 75.4 & $3.90 \mathrm{~m}$ & 75.0 & $4.18 \mathrm{~m}$ & 74.1 & $4.26 \mathrm{~m}$ & 74.6 & $4.25 \mathrm{~m}$ \\
\hline 4 & 80.7 & $4.10 \mathrm{~m}$ & 80.8 & $4.08 \mathrm{~m}$ & 80.3 & $4.21 \mathrm{~m}$ & 79.7 & $4.27 \mathrm{~m}$ & 81.0 & $4.26 \mathrm{~m}$ \\
\hline 5 & 65.8 & $3.58,4.35 \mathrm{~m}$ & 65.9 & $3.56,4.32 \mathrm{~m}$ & 65.3 & $3.74,4.38 \mathrm{~m}$ & 64.5 & $4.40,3.80 \mathrm{~m}$ & 64.9 & $3.78,4.41 \mathrm{~m}$ \\
\hline \multicolumn{11}{|c|}{ Rha I } \\
\hline 1 & 101.3 & $6.33 \mathrm{~s}$ & 101.2 & $6.34 \mathrm{~s}$ & 101.4 & $6.30 \mathrm{~s}$ & 101.8 & $6.15 \mathrm{~s}$ & 101.7 & $6.26 \mathrm{~s}$ \\
\hline 2 & 72.0 & $4.88 \mathrm{br} \mathrm{s}$ & 71.9 & $4.87 \mathrm{br} \mathrm{s}$ & 71.9 & $4.89 \mathrm{~m}$ & 72.3 & $4.71 \mathrm{~m}$ & 72.2 & $4.67 \mathrm{~m}$ \\
\hline 3 & 82.9 & $4.73 \mathrm{~m}$ & 82.9 & $4.75 \mathrm{~m}$ & 82.9 & $4.72 \mathrm{~m}$ & 72.6 & $4.59 \mathrm{~m}$ & 72.4 & $4.60 \mathrm{~m}$ \\
\hline 4 & 72.9 & $4.45 \mathrm{~m}$ & 73.0 & $4.47 \mathrm{~m}$ & 73.0 & $4.48 \mathrm{~m}$ & 74.1 & $4.28 \mathrm{~m}$ & 74.0 & $4.25 \mathrm{~m}$ \\
\hline 5 & 69.5 & $4.71 \mathrm{~m}$ & 69.6 & $4.72 \mathrm{~m}$ & 69.7 & $4.66 \mathrm{~m}$ & 69.8 & $4.62 \mathrm{~m}$ & 69.7 & $4.72 \mathrm{~m}$ \\
\hline 6 & 18.5 & $1.56 \mathrm{~d}(6.1)$ & 18.5 & $1.55 \mathrm{~d}(6.2)$ & 18.5 & $1.55 \mathrm{~d}(6.2)$ & 18.6 & $1.63 \mathrm{~d}(6.2)$ & 18.6 & $1.64 \mathrm{~d}(6.2)$ \\
\hline \multicolumn{11}{|c|}{ Xyl } \\
\hline 1 & 107.7 & $5.34 \mathrm{~d}(7.6)$ & 107.6 & $5.35 \mathrm{~d}(7.7)$ & 107.6 & $5.34 \mathrm{~d}(7.7)$ & & & & \\
\hline 2 & 75.6 & $4.03 \mathrm{~m}$ & 75.5 & $4.04 \mathrm{~m}$ & 75.6 & $4.05 \mathrm{~m}$ & & & & \\
\hline 3 & 78.5 & $4.13 \mathrm{~m}$ & 78.5 & $4.15 \mathrm{~m}$ & 78.5 & $4.14 \mathrm{~m}$ & & & & \\
\hline 4 & 71.1 & $4.12 \mathrm{~m}$ & 71.0 & $4.13 \mathrm{~m}$ & 71.1 & $4.16 \mathrm{~m}$ & & & & \\
\hline 5 & 67.4 & $3.68,4.45 \mathrm{~m}$ & 67.4 & $3.68,4.23 \mathrm{~m}$ & 67.5 & $3.73,4.32 \mathrm{~m}$ & & & & \\
\hline \multicolumn{11}{|c|}{ Glc I } \\
\hline 1 & 106.9 & $5.08 \mathrm{~d}(7.9)$ & 106.9 & $5.08 \mathrm{~d}(7.9)$ & 106.2 & $5.03 \mathrm{~d}(8.0)$ & 106.4 & $5.13 \mathrm{~d}(7.9)$ & 106.3 & $5.04 \mathrm{~d}(8.0)$ \\
\hline 2 & 75.5 & $3.99 \mathrm{~m}$ & 75.4 & $4.01 \mathrm{~m}$ & 74.9 & $4.00 \mathrm{~m}$ & 75.5 & $4.02 \mathrm{~m}$ & 74.9 & $3.99 \mathrm{~m}$ \\
\hline 3 & 78.5 & $4.18 \mathrm{~m}$ & 78.5 & $4.16 \mathrm{~m}$ & 76.7 & $4.18 \mathrm{~m}$ & 78.6 & $4.19 \mathrm{~m}$ & 76.7 & $4.17 \mathrm{~m}$ \\
\hline 4 & 71.2 & $4.20 \mathrm{~m}$ & 71.1 & $4.22 \mathrm{~m}$ & 81.3 & $4.29 \mathrm{~m}$ & 71.3 & $4.23 \mathrm{~m}$ & 81.3 & $4.28 \mathrm{~m}$ \\
\hline 5 & 78.8 & $3.85 \mathrm{~m}$ & 78.8 & $3.86 \mathrm{~m}$ & 76.7 & $3.83 \mathrm{~m}$ & 78.8 & $3.89 \mathrm{~m}$ & 76.7 & $3.82 \mathrm{~m}$ \\
\hline 6 & 62.5 & $4.33,4.45 \mathrm{~m}$ & 62.4 & $4.36,4.46 \mathrm{~m}$ & 61.8 & $4.41,4.51 \mathrm{~m}$ & 62.6 & $4.37,4.48 \mathrm{~m}$ & 61.8 & $4.40,4.51 \mathrm{~m}$ \\
\hline
\end{tabular}


Table 2. Cont.

\begin{tabular}{|c|c|c|c|c|c|c|c|c|c|c|}
\hline \multirow{2}{*}{$\mathrm{C}$} & \multicolumn{2}{|r|}{1} & \multicolumn{2}{|r|}{2} & \multicolumn{2}{|r|}{3} & \multicolumn{2}{|r|}{4} & \multicolumn{2}{|r|}{5} \\
\hline & $\delta_{\mathrm{C}}$ & $\delta_{\mathrm{H}}$ & $\delta_{\mathrm{C}}$ & $\delta_{\mathrm{H}}$ & $\delta_{\mathrm{C}}$ & $\delta_{\mathrm{H}}$ & $\delta_{\mathrm{C}}$ & $\delta_{\mathrm{H}}$ & $\delta_{\mathrm{C}}$ & $\delta_{\mathrm{H}}$ \\
\hline \multicolumn{11}{|c|}{ Glc IV } \\
\hline 1 & & & & & 105.1 & $5.15 \mathrm{~d}(7.8)$ & & & 105.1 & $5.15 \mathrm{~d}(7.8)$ \\
\hline 2 & & & & & 74.9 & $4.06 \mathrm{~m}$ & & & 74.9 & $4.05 \mathrm{~m}$ \\
\hline 3 & & & & & 78.3 & $4.19 \mathrm{~m}$ & & & 78.3 & $4.18 \mathrm{~m}$ \\
\hline 4 & & & & & 71.6 & $4.17 \mathrm{~m}$ & & & 71.5 & $4.17 \mathrm{~m}$ \\
\hline 5 & & & & & 78.4 & $3.99 \mathrm{~m}$ & & & 78.4 & $3.98 \mathrm{~m}$ \\
\hline 6 & & & & & 62.6 & $4.26,4.52 \mathrm{~m}$ & & & 62.5 & $4.27,4.53 \mathrm{~m}$ \\
\hline \multicolumn{11}{|c|}{28 - $O$-sugar } \\
\hline \multicolumn{11}{|c|}{ Glc II } \\
\hline 1 & 95.6 & $6.31 \mathrm{~d}(8.2)$ & 95.6 & $6.23 \mathrm{~d}(8.1)$ & 95.7 & $6.32 \mathrm{~d}(8.2)$ & 95.6 & $6.25 \mathrm{~d}(8.2)$ & 95.7 & $6.23 \mathrm{~d}(8.1)$ \\
\hline 2 & 74.1 & $4.19 \mathrm{~m}$ & 73.9 & $4.10 \mathrm{~m}$ & 74.2 & $4.20 \mathrm{~m}$ & 73.8 & $4.08 \mathrm{~m}$ & 73.8 & $4.11 \mathrm{~m}$ \\
\hline 3 & 79.3 & $4.03 \mathrm{~m}$ & 78.7 & $4.18 \mathrm{~m}$ & 79.3 & $4.02 \mathrm{~m}$ & 78.7 & $4.16 \mathrm{~m}$ & 78.7 & $4.17 \mathrm{~m}$ \\
\hline 4 & 71.2 & $4.35 \mathrm{~m}$ & 70.8 & $4.28 \mathrm{~m}$ & 71.2 & $4.37 \mathrm{~m}$ & 70.8 & $4.23 \mathrm{~m}$ & 70.7 & $4.29 \mathrm{~m}$ \\
\hline 5 & 78.9 & $4.27 \mathrm{~m}$ & 78.0 & $4.08 \mathrm{~m}$ & 78.9 & $4.28 \mathrm{~m}$ & 78.0 & $4.06 \mathrm{~m}$ & 78.0 & $4.08 \mathrm{~m}$ \\
\hline 6 & 62.2 & $4.41,4.44 \mathrm{~m}$ & 69.2 & $4.31,4.64 \mathrm{~m}$ & 62.3 & $4.41,4.46 \mathrm{~m}$ & 69.1 & $4.28,4.62 \mathrm{~m}$ & 69.0 & $4.31,4.63 \mathrm{~m}$ \\
\hline \multicolumn{11}{|c|}{ Glc III } \\
\hline 1 & & & 104.9 & $4.97 \mathrm{~d}(7.7)$ & & & 104.8 & $4.97 \mathrm{~d}(7.8)$ & 104.9 & $4.98 \mathrm{~d}(7.8)$ \\
\hline 2 & & & 75.3 & $3.92 \mathrm{~m}$ & & & 75.3 & $3.93 \mathrm{~m}$ & 75.3 & $3.93 \mathrm{~m}$ \\
\hline 3 & & & 76.5 & $4.12 \mathrm{~m}$ & & & 76.5 & $4.12 \mathrm{~m}$ & 76.4 & $4.14 \mathrm{~m}$ \\
\hline 4 & & & 78.2 & $4.40 \mathrm{~m}$ & & & 78.2 & $4.39 \mathrm{~m}$ & 78.0 & $4.39 \mathrm{~m}$ \\
\hline 5 & & & 77.1 & $3.62 \mathrm{~m}$ & & & 77.1 & $3.64 \mathrm{~m}$ & 77.1 & $3.63 \mathrm{~m}$ \\
\hline 6 & & & 61.2 & $4.07,4.18 \mathrm{~m}$ & & & 61.2 & $4.07,4.17 \mathrm{~m}$ & 61.1 & $4.08,4.18 \mathrm{~m}$ \\
\hline \multicolumn{11}{|c|}{ Rha II } \\
\hline 1 & & & 102.7 & $5.84 \mathrm{~s}$ & & & 102.7 & $5.84 \mathrm{~s}$ & 102.7 & $5.85 \mathrm{~s}$ \\
\hline 2 & & & 72.6 & $4.66 \mathrm{~m}$ & & & 72.5 & $4.65 \mathrm{~m}$ & 72.6 & $4.65 \mathrm{~m}$ \\
\hline 3 & & & 72.7 & $4.53 \mathrm{~m}$ & & & 72.7 & $4.52 \mathrm{~m}$ & 72.7 & $4.53 \mathrm{~m}$ \\
\hline 4 & & & 74.0 & $4.31 \mathrm{~m}$ & & & 74.0 & $4.30 \mathrm{~m}$ & 74.0 & $4.32 \mathrm{~m}$ \\
\hline 5 & & & 70.3 & $4.95 \mathrm{~m}$ & & & 70.3 & $4.94 \mathrm{~m}$ & 70.2 & $4.95 \mathrm{~m}$ \\
\hline 6 & & & 18.5 & $1.68 \mathrm{~d}(6.2)$ & & & 18.5 & $1.68 \mathrm{~d}(6.2)$ & 18.5 & $1.62 \mathrm{~d}(6.2)$ \\
\hline
\end{tabular}

Figure 2. Key NOESY and HMBC correlations for compound 1.

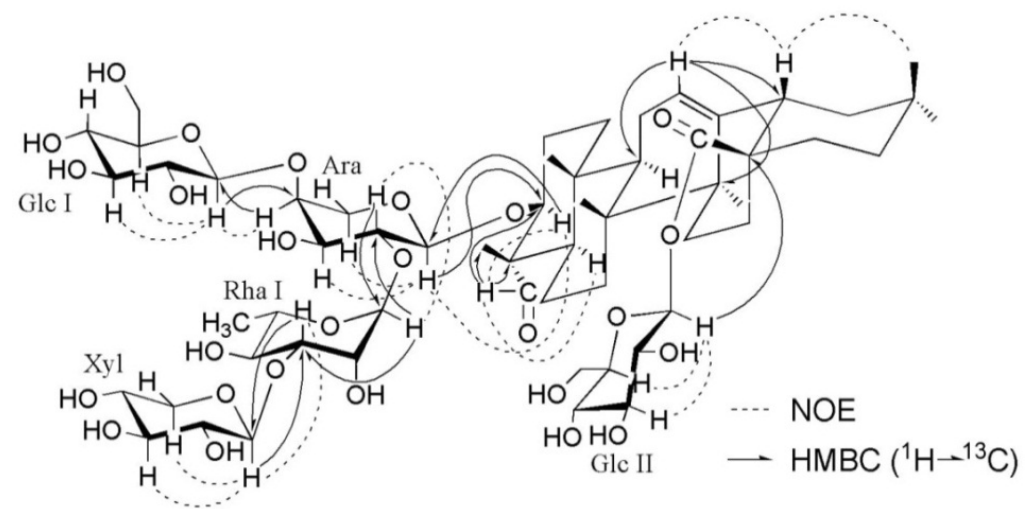


The sugar moieties of $\mathbf{1}$ were determined to be L-arabinose (Ara), D-xylose (Xyl), L-rhamnose (Rha) and D-glucose (Glc) in a ratio of 1:1:1:2 by acidic hydrolysis followed by comparison of the GC retention times of the corresponding trimethylsilylated hydrolysates with those of the authentic samples prepared in the same manner in the literature [19]. Meanwhile, the ${ }^{1} \mathrm{H}-\mathrm{NMR}$ spectrum of compound 1 exhibited five anomeric protons at $\delta_{\mathrm{H}}=6.33(\mathrm{~s}), 6.31(\mathrm{~d}, J=8.2 \mathrm{~Hz}), 5.34(\mathrm{~d}, J=7.6 \mathrm{~Hz})$, $5.08(\mathrm{~d}, J=7.9 \mathrm{~Hz})$ and $4.92(\mathrm{~d}, J=7.1 \mathrm{~Hz})$, and one methyl group of a 6-deoxyhexopyranosyl moiety at $\delta_{\mathrm{H}} 1.56(\mathrm{~d}, J=6.1 \mathrm{~Hz})$. The $\beta$-anomeric configurations for the xylose and glucose units were deduced from their ${ }^{3} J_{\mathrm{H}-1 / \mathrm{H}-2}$ coupling constants $(7.6-8.2 \mathrm{~Hz})$. The arabinose unit was determined to have an $\alpha$-anomeric configuration on the basis of the ${ }^{3} J_{\mathrm{H}-1 / \mathrm{H}-2}(7.1 \mathrm{~Hz})$ value observed in the ${ }^{4} C_{1}$ form. Although the anomeric proton of the rhamnose moiety was observed as a singlet in the ${ }^{1} \mathrm{H}-\mathrm{NMR}$ spectrum, the ${ }^{13} \mathrm{C}-\mathrm{NMR}$ shift of Rha C-5 at $\delta_{\mathrm{C}}=69.5$ indicated the $\alpha$-anomeric configuration [20,21]. All proton signals due to sugars were identified by careful analysis of the ${ }^{1} \mathrm{H}-{ }^{1} \mathrm{H}$ COSY, TOCSY and NOESY spectra, and the carbon signals were assigned by HSQC and further confirmed by HMBC spectra (Table 1). All the monosaccharides were determined to be in their pyranose forms from their ${ }^{13} \mathrm{C}-\mathrm{NMR}$ data. The sequence and binding sites of the oligosaccharide chains were unambiguously defined by the HMBC experiment. A cross peak between $\mathrm{C}-3$ of the aglycone and $\mathrm{H}-1$ of Ara indicated that Ara was connected to C-3 of the aglycone and a cross peak between C-28 of the aglycone and H-1 of one of the glucose units (Glc II) indicated that Glc II was linked to C-28 of the aglycone.

Similarly, the linkage of one of the glucose units (Glc I) at C-4 of Ara was indicated by the cross peak Glc I H-1/Ara C-4, and the linkages of the terminal xyl at the C-3 of Rha in turn linked to C-2 of Ara were indicated by cross peaks Xyl H-1/Rha C-3 and Rha H-1/Ara C-2. The conclusion was confirmed by the NOESY correlations as shown in Figure 2. On the basis of the above analysis, the structure of compound 1 was thus elucidated as 3-O- $\beta$-D-xylopyranosyl-( $1 \rightarrow 3)$ - $\alpha$-L-rhamnopyranosyl- $(1$ $\rightarrow 2$ )-[ $\beta$-D-glucopyranosyl-( $(1 \rightarrow 4)]$ - $\alpha$-L-arabinopyranosyl gypsogenin $28-O-\beta$-D-glucopyranosyl ester.

Compound 2 was also obtained as a white powder, and showed positive Liebermann-Burchard and Molisch reactions. HRESIMS of 2 showed the quasi-molecular ion at $m / z \quad 1,535.6885$ (calcd. for $[\mathrm{M}+\mathrm{Na}]^{+}$1,535.6882), establishing a molecular formula of $\mathrm{C}_{70} \mathrm{H}_{112} \mathrm{O}_{35}$. The ${ }^{1} \mathrm{H}-$ and ${ }^{13} \mathrm{C}-\mathrm{NMR}$ data assignable to the aglycone moiety of $\mathbf{2}$ were identical to those of $\mathbf{1}$ (Table 1), suggesting the aglycone to also be gypsogenin. Seven anomeric protons $\left[\delta_{\mathrm{H}} 6.34(\mathrm{~s}), 6.23(\mathrm{~d}, J=8.1 \mathrm{~Hz}), 5.84\right.$ (s), 5.35 (d, $J=7.7 \mathrm{~Hz}), 5.08(\mathrm{~d}, J=7.9 \mathrm{~Hz}), 4.97(\mathrm{~d}, J=7.7 \mathrm{~Hz})$ and $4.91(\mathrm{~d}, J=7.2 \mathrm{~Hz})]$ and seven anomeric carbons $\left(\delta_{\mathrm{C}} 107.6,106.9,104.9,104.6,102.7,101.2\right.$ and 95.6) were observed in the NMR spectra of 2. Acid hydrolysis and GC analyses of 2 confirmed the NMR data of the sugar moieties, indicating the units as $\alpha$-L-arabinose, $\alpha$-L-rhamnose, $\beta$-D-glucose and $\beta$-D-xylcose in a 1:2:3:1 ratio (Table 2).

The linkage points of the sugar units to each other and to C-3 and C-28 of the aglycone were established from the HMBC correlations of signals at $\delta_{\mathrm{H}} 4.91\left(\mathrm{H}-1\right.$ of Ara) with $\delta_{\mathrm{C}} 81.7$ (C-3 of the aglycone), $\delta_{\mathrm{H}} 6.34$ (H-1 of Rha I) with $\delta_{\mathrm{C}} 75.5$ (C-2 of Ara), $\delta_{\mathrm{H}} 5.35$ (H-1 of Xyl ) with $\delta_{\mathrm{C}} 82.9$ (C-3 of Rha I), $\delta_{\mathrm{H}} 5.08$ (H-1 of Glc I) with $\delta_{\mathrm{C}} 80.8$ (C-4 of Ara), $\delta_{\mathrm{H}} 6.23$ (H-1 of Glc II) with $\delta_{\mathrm{C}} 176.5$ (C-28 of the aglycone), $\delta_{\mathrm{H}} 4.97$ (H-1 of Glc III) with $\delta_{\mathrm{C}} 69.2$ (C-6 of Glc II) and $\delta_{\mathrm{H}} 5.84$ (H-1 of Rha II) with $\delta_{\mathrm{C}} 78.2$ (C-4 of Glc III) (Figure S1 in the Supplementary Data). Accordingly, compound 2 was identified as 3-O- $\beta$ D-xylopyranosyl- $(1 \rightarrow 3)$ - $\alpha$-L-rhamnopyranosyl-( $1 \rightarrow 2)$-[ $\beta$-D-glucopyranosyl-( $(1 \rightarrow 4)]$ - $\alpha$-L-arabino-pyranosyl gypsogenin $28-O$ - $\alpha$-L-rhamnopyranosyl- $(1 \rightarrow 4)-\beta$-D-glucopyranosyl- $(1 \rightarrow 6)-\beta$-D-glucopyranosyl ester. 
Compound 3 was positive to Liebermann-Burchard and Molisch tests. The molecular formula was established as $\mathrm{C}_{64} \mathrm{H}_{104} \mathrm{O}_{30}$ from the $[\mathrm{M}+\mathrm{Na}]^{+}$ion at $\mathrm{m} / z=1,375.6507$ (calcd. for $\mathrm{C}_{70} \mathrm{H}_{114} \mathrm{O}_{34} \mathrm{Na}^{+}$, 1,375.6510) in the positive ion mode HRESIMS. The analysis of the NMR data (Tables 1 and 2) indicated that $\mathbf{3}$ was a saponin containing one triterpene aglycone and six monosaccharides. The aglycone of 3 was recognized to be oleanolic acid by ${ }^{1} \mathrm{H}$ - and ${ }^{13} \mathrm{C}-\mathrm{NMR}$ analysis (Table 1), which was in full agreement with literature data [21]. The chemical shifts of C-3 $\left(\delta_{\mathrm{C}}=88.6\right)$ and C-28 $\left(\delta_{\mathrm{C}}=176.5\right)$ revealed that 3 was a bisdesmosidic glycoside. The presence of L-arabinose (Ara), D-xylose (Xyl), L-rhamnose (Rha) and D-glucose (Glc) in a 1:1:2:2 ratio was established by acid hydrolysis followed by $\mathrm{GC}$ analysis of the corresponding derivatives. Complete ${ }^{1} \mathrm{H}$ - and ${ }^{13} \mathrm{C}-\mathrm{NMR}$ assignments of the sugar part were achieved by a combination of 2D-NMR experiments (Table 2). The NMR data of the sugar part of $\mathbf{3}$ were very similar to those obtained from 1, except for a significant downfield shift of C-4 $\left(\delta_{\mathrm{C}}=81.3\right)$ of Glc I and the appearance of a set of additional signals, corresponding to a terminal $\beta$-D-glucopyranosyl group (Glc IV) in 3 which was attached at C-4 of Glc I. The sequence and binding sites of the sugar units connected to C-3 and C-28 of the aglycone were confirmed by the HMBC and NOESY correlations (Figure S2 in Supplementary Data). Hence, compound 3 was established as 3-O- $\beta$ D-xylopyranosyl-( $1 \rightarrow 3)-\alpha-L-r h a m n o p y r a n o s y l-(1 \rightarrow 2)$-[ $\beta$-D-glucopyranosyl-( $1 \rightarrow 4)-\beta$-D-gluco-pyranosyl$(1 \rightarrow 4)]$ - $\alpha$-L-arabinopyranosyl oleanolic acid $28-O-\beta$-D-glucopyranosyl ester.

Compound 4 was obtained as white amorphous powder and showed positive results to the Liebermann-Burchard and Molisch tests. In the positive-ion mode HRESIMS, a pseudomolecular ion peak at $m / z 1,405.6612[\mathrm{M}+\mathrm{Na}]^{+}$(calcd. for $\mathrm{C}_{65} \mathrm{H}_{106} \mathrm{O}_{31} \mathrm{Na}^{+}, 1,405.6616$ ) was observed, which is consistent with a molecular formula $\mathrm{C}_{65} \mathrm{H}_{106} \mathrm{O}_{31}$. The 1D-NMR data of 4 exhibited signals for seven tertiary methyl groups at $\delta_{\mathrm{H}} 0.87\left(\mathrm{H}_{3}-25\right), 1.00\left(\mathrm{H}_{3}-30\right), 1.09\left(\mathrm{H}_{3}-26\right), 1.14\left(\mathrm{H}_{3}-29\right), 1.16\left(\mathrm{H}_{3}-24\right), 1.29\left(\mathrm{H}_{3}-23\right)$ and $1.33\left(\mathrm{H}_{3}-27\right)$, one olefinic proton at $\delta_{\mathrm{H}} 5.43\left(1 \mathrm{H}\right.$, br s) with two typical olefinic carbon signals at $\delta_{\mathrm{C}}$ 122.8 and 144.2, and one carbonyl signal at $\delta_{\mathrm{C}} 176.5$, which revealed that the aglycone of 4 was a derivative of oleanolic acid. Comparison of their chemical shifts between the aglycone and oleanolic acid indicated that they were the same except for the E-ring. Due to the change of chemical shift of C-21 from $\delta_{\mathrm{C}} 31.4$ in oleanolic acid [22] to $\delta_{\mathrm{C}} 73.3(+41.9)$ and the other of carbons such as C-18 [ $\left.\delta_{\mathrm{C}} 41.7(-1.2)\right], \mathrm{C}-19\left[\delta_{\mathrm{C}} 41.3(-5.0)\right], \mathrm{C}-20\left[\delta_{\mathrm{C}} 35.7(+4.8)\right], \mathrm{C}-22\left[\delta_{\mathrm{C}} 39.6(+6.4)\right], \mathrm{C}-29\left[\delta_{\mathrm{C}} 28.3(-6.9)\right]$ and $\mathrm{C}-30\left[\delta_{\mathrm{C}} 24.9(+0.2)\right], \mathrm{C}-21$ must be an oxygen-bearing methylene carbon in the aglycone of 4 , which was confirmed by the DEPT experiment. In the HMBC experiment, the correlation peaks $\mathrm{H}_{3}-29 / \mathrm{C}-21$ and $\mathrm{H}_{3}-30 / \mathrm{C}-21$ also allowed the location of a hydroxyl group at C-21 (Figure S3 in Supplementary data). The NOESY correlations between $\mathrm{H}-21\left(\delta_{\mathrm{H}} 3.65\right)$ and $\mathrm{H}_{3}-30\left(\delta_{\mathrm{H}} 1.00\right)$ indicated the $\alpha$-orientation of $21-\mathrm{OH}$. The assignments of the NMR signals associated with the aglycone moiety were derived from ${ }^{1} \mathrm{H}-{ }^{1} \mathrm{H}$ COSY, TOCSY, HSQC, HMBC and NOESY experiments. These data revealed the aglycone of 4 was $21 \alpha$-hydroxy-oleanolic acid, which was in a good agreement with the literature data $[23,24]$. The ${ }^{1} \mathrm{H}$ - and ${ }^{13} \mathrm{C}-\mathrm{NMR}$ spectra assignable to the sugar moieties of $\mathbf{4}$ were similar to those of 2 except for the absence of proton and carbon resonances for a terminal $\beta$-D-xylose moiety. The sequence and binding sites of the sugar units to each other and to the aglycone were confirmed by the HMBC and NOESY correlations (Figure S3 in the Supplementary Data). On the basis of the above

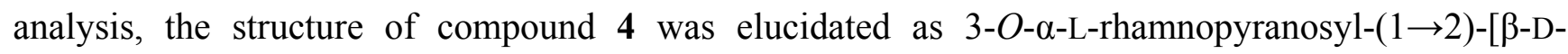
glucopyranosyl- $(1 \rightarrow 4)$ ]- $\alpha$-L-arabinopyranosyl $21 \alpha$-hydroxyoleanolic acid 28 - $O$ - $\alpha$-L-rhamnopyranosyl$(1 \rightarrow 4)-\beta$-D-glucopyranosyl-( $1 \rightarrow 6)-\beta$-D-glucopyranosyl ester. 
Compound $\mathbf{5}$ was also obtained as a white powder, showed positive Libermann-burchard and Molisch reactions. HRESIMS of 5 showed the quasi-molecular ion at $\mathrm{m} / z$ 1,567.7150 (calcd. for $[\mathrm{M}+\mathrm{Na}]^{+}$1,567.7144), establishing the molecular formula of $\mathrm{C}_{71} \mathrm{H}_{116} \mathrm{O}_{36}$. The 1D-NMR data assignable to the aglycone moiety of 5 were identical to those of $\mathbf{4}$ (Table 1), suggesting the aglycone also to be $21 \alpha$-hydroxy-oleanolic acid. The ${ }^{1} \mathrm{H}$ - and ${ }^{13} \mathrm{C}$-NMR spectra assignable to the sugar moieties of $\mathbf{5}$ were similar to those of $\mathbf{4}$ except for the presence of proton and carbon resonances for an additional $\beta$-D-glucopyranose moiety (Glc IV). The downfield-shifted carbon signal of Glc I C-4 $\left(\delta_{\mathrm{C}} 81.3\right)$ in the ${ }^{13} \mathrm{C}-\mathrm{NMR}$ spectrum and the presence of a correlation between Glc IV H-1 $\left(\delta_{\mathrm{H}} 5.15\right)$ and Glc I C-4 $\left(\delta_{\mathrm{C}} 5.15\right)$ in the HMBC spectrum indicated that Glc IV was attached to Glc I C-4. The conclusion was confirmed by the NOESY correlations (Figure S4 in the Supplementary Data). Hence, compound 5 was established as 3-O- $\beta$-D-glucopyranosyl-( $1 \rightarrow 4)-\beta$-D-glucopyranosyl-( $1 \rightarrow 4)$-[ $\alpha$-L-rhamno-pyranosyl$(1 \rightarrow 2)$ ]- $\alpha$-L-arabinopyranosyl $21 \alpha$-hydroxyoleanolic acid $28-O$ - $\alpha$-L-rhamnopyranosyl-( $1 \rightarrow 4)-\beta$-Dglucopyranosyl-( $1 \rightarrow 6)-\beta$-D-glucopyranosyl ester.

By comparing their physical and spectroscopic data with those reported in the literature, the known compounds were identified as sapindoside B (6) [25], pulsatilla saponin D (7) [26], 3-O- $\beta$-Dxylopyranosyl-( $1 \rightarrow 3)$ - $\alpha$-L-rhamnopyranosyl-( $1 \rightarrow 2)$-[ $\beta$-D-glucopyranosyl-( $1 \rightarrow 4)]$ - $\alpha$-L-arabinopyranosyl oleanolic acid (8) [27], sieboldianoside B (9) [28], and 3-O- $\alpha$-L-arabinopyranosyl gypsogenin 28-O- $\alpha$ L-rhamnopyranosyl-( $1 \rightarrow 4)-\beta$-D-glucopyranosyl-( $1 \rightarrow 6)-\beta$-D-glucopyranosyl ester $(\mathbf{1 0})$ [11], respectively.

The cytotoxic activity of saponins 1-10 against human leukemia HL-60 cells, human hepatocellular carcinoma HepG2 cells, human lung carcinoma A549 cells and human cervical carcinoma HeLa cells were evaluated by MTT colorimetric assay. Doxorubicin was used as positive control.

The $\mathrm{IC}_{50}$ value of each compound was measured on the basis of cell viability after $72 \mathrm{~h}$ treatment. As shown in Table 3, all monodesmosidic saponins 6-8, which possess oligosaccharide chains at C-3 and a free carboxylic acid at C-28 of the aglycone, exhibited cytotoxic activity against all tested cancer cell lines with $\mathrm{IC}_{50}$ values ranging from 7.25 to $22.38 \mu \mathrm{M}$. The bisdesmosidic saponins $\mathbf{2 , 4 , 5 , 9}$ and 10, which possess the same $\alpha$-L-rhamnopyranosyl-( $1 \rightarrow 4)$ - $\beta$-D-glucopyranosyl-( $1 \rightarrow 6)-\beta$-D-gluco-pyranosyl oligosaccharide chain at $\mathrm{C}-28$, were all inactive. Earlier studies on the cytotoxicity of similar compounds have reached the same results $[29,30]$.

Table 3. Cytotoxic activity of compounds 1-10 against four human cancer cell lines in vitro.

\begin{tabular}{ccccc}
\hline \multirow{2}{*}{ Compounds $^{\text {a }}$} & \multicolumn{4}{c}{ Cytotoxic activity $\left(\mathbf{I C}_{\mathbf{5 0}}, \boldsymbol{\mu M}\right.$; mean \pm SD, $\left.\boldsymbol{n}=\mathbf{3}\right)$} \\
\cline { 2 - 5 } & HL-60 & HepG2 & A549 & HeLa \\
\hline $\mathbf{1}$ & $82.16 \pm 2.79$ & $>100$ & $>100$ & $>100$ \\
$\mathbf{3}$ & $45.32 \pm 1.74$ & $55.79 \pm 2.57$ & $75.68 \pm 2.79$ & $>100$ \\
$\mathbf{6}$ & $12.32 \pm 0.41$ & $13.25 \pm 0.38$ & $19.42 \pm 0.67$ & $22.20 \pm 0.42$ \\
$\mathbf{7}$ & $9.57 \pm 0.54$ & $10.64 \pm 0.47$ & $22.38 \pm 0.72$ & $17.31 \pm 0.81$ \\
$\mathbf{8}$ & $7.25 \pm 0.31$ & $12.11 \pm 0.87$ & $9.89 \pm 0.57$ & $15.47 \pm 0.73$ \\
Doxorubicin $^{\mathrm{b}}$ & $0.35 \pm 0.05$ & $0.50 \pm 0.04$ & $0.68 \pm 0.10$ & $0.66 \pm 0.07$ \\
\hline
\end{tabular}

HL-60-humanpromyelocyticleukemia cell line; HepG2-human hepatocellular carcinoma cell line; A549_-human lung carcinoma cell line; HeLa_human cervical carcinoma cell line; ${ }^{a}$ Compounds 2, 4, 5, 9 and 10 were inactive $\left(\mathrm{IC}_{50}>100 \mu \mathrm{M}\right)$ for all cell lines; ${ }^{\mathrm{b}}$ Doxorubicin was used as positive control. 
Interestingly, the remaining two bisdesmosidic saponins $\mathbf{1}$ and $\mathbf{3}$ showed moderate cytotoxicity (1 against HL-60; 3 against HL-60, HeLa and A549). This may be ascribed to the fact that these two saponins only possess one sugar moiety at C-28 of the aglycone. Therefore, we postulated that the shorter oligosaccharide chain at C-28 the better cytotoxic activity the saponins would exhibit.

\section{Experimental}

\subsection{General}

Optical rotations were measured on a Perkin-Elmer 343 polarimeter. The ESIMS and HRESIMS were measured on a Micromass Quattro mass spectrometer. NMR experiments were performed on a Bruker AVANCE-500 spectrometer in pyridine- $d_{5}$ (99.95\%, Sigma-Aldrich) with TMS as internal standard. GC was performed on a Finnigan Voyager apparatus using an L-Chirasil-Val column $\left(0.32 \mathrm{~mm} \times 25 \mathrm{~m}\right.$; injector temperature: $230{ }^{\circ} \mathrm{C}$; column temperature: $100-180{ }^{\circ} \mathrm{C}$, rate $5{ }^{\circ} \mathrm{C} / \mathrm{min}$; column head pressure: $12 \mathrm{~Pa}$; carrier gas: He, $2 \mathrm{~mL} / \mathrm{min}$ ). HPLC was carried out on a Dionex P680 liquid chromatograph equipped with a UV $170 \mathrm{UV} / V$ is detector at $206 \mathrm{~nm}$ using a Diamonsil C18(2) column $(21.2 \times 250 \mathrm{~mm}$ i.d., $5 \mu \mathrm{m}$, Dikma Technologies Inc., Lake Forest, CA, USA). Materials for column chromatography (CC) were silica gel (10-40 $\mu \mathrm{m}$, Qingdao Marine Chemical Inc., Qingdao, China), Sephadex LH-20 (40-70 $\mu \mathrm{m}$, GE-Healthcare, Uppsala, Sweden), and reversed phase silica gel ODS-A (50 $\mu \mathrm{m}$, YMC Co., Ltd, Kyoto, Japan). TLC detection was achieved by spraying the silica gel plates (Qingdao Marine Chemical Inc) with $20 \% \mathrm{H}_{2} \mathrm{SO}_{4}$-EtOH $(v / v)$ solution followed by heating. The Liebermann-Burchardtest was made with acetic anhydride and sulfuric acid, and the Molisch test was made with $\alpha$-naphthol and sulfuric acid. Chemical reagents for isolation were of analytical grade and purchased from Tianjin Fuyu Chemical Co. Ltd. (Tianjin, China).

\subsection{Plant Material}

The rhizomes of Anemone rivularis var. flore-minore were collected on Taibai Mountain, Shaanxi Province, China, in September 2012, and identified by Prof. Ji-Tao Wang (Department of Pharmacognosy, School of Pharmacy, Shaanxi University of Chinese Medicine). A voucher specimen (NO.120922) has been deposited in the Herbarium of Shaanxi University of Chinese Medicine.

\subsection{Extraction and Isolation}

The air-dried rhizomes of $A$. rivularis var. flore-minore $(8 \mathrm{~kg})$ were powdered and extracted with $70 \% \mathrm{EtOH}(16 \mathrm{~L})$ under reflux for three times (each for $2 \mathrm{~h}$ ). The extract was evaporated in vacuo to yield a residue $(1,300 \mathrm{~g})$ which was suspended in water $(10 \mathrm{~L})$ and partitioned successively with petroleum ether $(10 \mathrm{~L} \times 2)$ and $n-\mathrm{BuOH}(10 \mathrm{~L} \times 2)$. The $n-\mathrm{BuOH}$ extract $(160 \mathrm{~g})$ was separated by silica gel $\mathrm{CC}$ using a stepwise gradient of $\mathrm{CHCl}_{3}-\mathrm{MeOH}-\mathrm{H}_{2} \mathrm{O}$ (10:1:0.05-6:4:0.8) to give nine fractions (Fr. 1-Fr. 9). Fr. 3 (4.5 g) was subject to silica gel $\mathrm{CC}$ with a $\mathrm{CHCl}_{3}-\mathrm{MeOH}-\mathrm{H}_{2} \mathrm{O}$ gradient $(10: 1: 0.1-7: 3: 0.5)$ to give five sub-fractions (Fr. 3.1-Fr. 3.5). Fr. $3.2(0.8 \mathrm{~g})$ and Fr. 3.3 (1.2 g) were submitted to gel permeation chromatography on Sephadex LH-20 in MeOH to remove the pigments and carbohydrates, and further purified by semipreparative HPLC to give compound 6 [35 $\mathrm{mg}$, $\mathrm{MeOH}-\mathrm{H}_{2} \mathrm{O}(75: 25), 8 \mathrm{~mL} / \mathrm{min}, t_{\mathrm{R}} 22.0 \mathrm{~min}$ ] and compound 7 [42 $\mathrm{mg}, \mathrm{MeOH}-\mathrm{H}_{2} \mathrm{O}(78: 22), 8 \mathrm{~mL} / \mathrm{min}$, 
$t_{\mathrm{R}} 19.5 \mathrm{~min}$ ], respectively. Fr. 4 (3.5 g) was separated by silica gel CC with a stepwise gradient of $\mathrm{CHCl}_{3}-\mathrm{MeOH}-\mathrm{H}_{2} \mathrm{O}$ gradient (10:1:0.1-7:3:0.5) to yield three fractions (Fr. 4.1-Fr. 4.3). Compound 8 $\left(26 \mathrm{mg}\right.$ ) was obtained from Fr. 4.2 by semipreparative HPLC [MeOH-H${ }_{2} \mathrm{O}(82: 18), 8 \mathrm{~mL} / \mathrm{min}, t_{\mathrm{R}}$ $16.5 \mathrm{~min}]$. Fr. $6(2.1 \mathrm{~g})$ and Fr. $7(15.5 \mathrm{~g})$ were subjected to ODS CC using a stepwise gradient $\left[\mathrm{MeOH}-\mathrm{H}_{2} \mathrm{O}(1: 4-10: 1)\right]$ to afford Fr. 6.1-Fr. 6.5 and Fr. 7.1-Fr. 7.6, respectively. Fr. $6.2(0.9 \mathrm{~g})$ were submitted to Sephadex LH-20 CC in $\mathrm{MeOH}$ and further purified by semipreparative HPLC [MeOH- $\mathrm{H}_{2} \mathrm{O}(75: 25), 8 \mathrm{~mL} / \mathrm{min}$ ) to yield compound $9\left(35 \mathrm{mg}, t_{\mathrm{R}} 19.7 \mathrm{~min}\right)$ and compound $\mathbf{3}$ (26 mg, $\left.t_{\mathrm{R}} 25.2 \mathrm{~min}\right)$. Fr. $7.2(1.1 \mathrm{~g})$ and Fr. $7.3(1.5 \mathrm{~g})$ were subjected to semipreparative HPLC after CC over Sephadex LH-20 (MeOH), to give compound 10 [45 mg, MeOH-H ${ }_{2} \mathrm{O}(62: 38), 6.5 \mathrm{~mL} / \mathrm{min}, t_{\mathrm{R}} 18.5$ min from Fr. 7.2], compound 1 [24 mg, $\mathrm{MeOH}-\mathrm{H}_{2} \mathrm{O}$ (55:45), $6.0 \mathrm{~mL} / \mathrm{min}, t_{\mathrm{R}} 29.3 \mathrm{~min}$ from Fr. 7.3] and compound 2 [30 mg, $\mathrm{MeOH}-\mathrm{H}_{2} \mathrm{O}(55: 45), 6.0 \mathrm{~mL} / \mathrm{min}, t_{\mathrm{R}} 35.8 \mathrm{~min}$ from Fr. 7.3]. Fr. 7.4 (8.6 g) was separated by ODS $\mathrm{CC}$ again eluting with a gradient of $\mathrm{MeOH}-\mathrm{H}_{2} \mathrm{O}(1: 10-5: 1)$ to afford Fr. 7.4.1-Fr. 7.4.6. Compound 4 [15 mg, $\left.\mathrm{MeOH}-\mathrm{H}_{2} \mathrm{O}(70: 30), 8 \mathrm{~mL} / \mathrm{min}, t_{\mathrm{R}} 18.5 \mathrm{~min}\right]$ and Compound 5 $\left(19 \mathrm{mg}, \mathrm{MeOH}-\mathrm{H}_{2} \mathrm{O}(65: 35), 7 \mathrm{~mL} / \mathrm{min}, t_{\mathrm{R}} 25.6 \mathrm{~min}\right)$ were obtained from Fr. 7.4 .2 and 7.4.3, respectively. Purities of these compounds were determined $>95 \%$ by HPLC.

Compound 1: White amorphous powder; $[\alpha]_{\mathrm{D}}^{22}+12.3(c \quad 0.16, \mathrm{MeOH}) ;{ }^{1} \mathrm{H}-$ and ${ }^{13} \mathrm{C}-\mathrm{NMR}$ data, see Tables 1 and 2; key HMBC and NOESY correlations, see Figure 2; ESIMS (pos. ion mode) m/z 1227 $[\mathrm{M}+\mathrm{Na}]^{+}$; ESIMS (neg. ion mode) m/z $1203[\mathrm{M}-\mathrm{H}]^{-}, 1071[1203-132]^{-}, 1041$ [1203-162] $]^{-}, 925$ [1071-146] $]^{-}, 909$ [1071-162], 879 [1041-162] $]^{-}$HRESIMS (pos. ion mode) $\mathrm{m} / \mathrm{z} 1227.5779$ [M+Na] (calcd. for $\mathrm{C}_{58} \mathrm{H}_{92} \mathrm{NaO}_{26}, 1227.5775$ ).

Compound 2: White amorphous powder; $[\alpha]_{\mathrm{D}}^{22}-8.2(c \mathrm{c} .18, \mathrm{MeOH}) ;{ }^{1} \mathrm{H}-$ and ${ }^{13} \mathrm{C}-\mathrm{NMR}$ data, see Tables 1 and 2; key HMBC and NOESY correlations, see Figure S1 in the Supplementary Data; ESIMS (pos. ion mode) $m / z 1535[\mathrm{M}+\mathrm{Na}]^{+}, 1065$ [1535-146-162-162] $]^{+}$ESIMS (neg. ion mode) $m / z 1511[\mathrm{M}-\mathrm{H}]^{-}$, 1379 [1511-132], 1349 [1511-162] ${ }^{-}, 1041$ [1511-146-162-162] $]^{-}$HRESIMS (pos. ion mode) $\mathrm{m} / \mathrm{z}$ $1535.6885[\mathrm{M}+\mathrm{Na}]^{+}$(calcd. for $\mathrm{C}_{70} \mathrm{H}_{112} \mathrm{NaO}_{35}, 1535.6882$ ).

Compound 3: White amorphous powder; $[\alpha]_{\mathrm{D}}^{22}-15.4(c \quad 0.20, \mathrm{MeOH}) ;{ }^{1} \mathrm{H}$ - and ${ }^{13} \mathrm{C}-\mathrm{NMR}$ data, see Tables 1 and 2; key HMBC and NOESY correlations, see Figure S2 in the Supplementary Data; ESIMS (pos. ion mode) $m / z 1375[\mathrm{M}+\mathrm{Na}]^{+}, 1243[1375-132]^{+}, 1213[1375-162]^{+}, 1081[1243-162]^{+}$, 1051 [1213-162] ${ }^{+}$; ESIMS (neg. ion mode) m/z $1351[\mathrm{M}-\mathrm{H}]^{-}, 1219$ [1351-132]-, 1189 [1351-162]-, 1027 [1189-162] ; HRESIMS (pos. ion mode) $m / z$ 1375.6507 $[\mathrm{M}+\mathrm{Na}]^{+}$(calcd. for $\mathrm{C}_{70} \mathrm{H}_{114} \mathrm{NaO}_{34}$, 1375.6510).

Compound 4: White amorphous powder; $[\alpha]_{\mathrm{D}}^{22}+7.2(c 0.11, \mathrm{MeOH}) ;{ }^{1} \mathrm{H}$ - and ${ }^{13} \mathrm{C}-\mathrm{NMR}$ data, see Tables 1 and 2; key HMBC and NOESY correlations, see Figure S3 in the Supplementary Data; ESIMS (pos. ion mode) $m / z 1405[\mathrm{M}+\mathrm{Na}]^{+}, 1259[1405-146]^{+}, 1243[1405-162]^{+}, 935[1405-146-162-162]^{+}$; ESIMS (neg. ion mode) $m / z 1381[\mathrm{M}-\mathrm{H}]^{-}, 911$ [1381-146-162-162] ${ }^{-}$; HRESIMS (pos. ion mode) $m / z 1405.6612[\mathrm{M}+\mathrm{Na}]^{+}$(calcd. for $\mathrm{C}_{65} \mathrm{H}_{106} \mathrm{NaO}_{31}, 1405.6616$ ).

Compound 5: White amorphous powder; $[\alpha]_{\mathrm{D}}^{22}-9.4(c 0.18, \mathrm{MeOH}) ;{ }^{1} \mathrm{H}$ - and ${ }^{13} \mathrm{C}-\mathrm{NMR}$ data, see Tables 1 and 2; key HMBC and NOESY correlations, see Figure S4 in the Supplementary Data; ESIMS (pos. 
ion mode) $m / z 1567[\mathrm{M}+\mathrm{Na}]^{+}, 1421[1567-146]^{+}, 1405[1567-162]^{+}, 1097[1567-146-162-162]^{+}$; ESIMS (neg. ion mode) $m / z 1543[\mathrm{M}-\mathrm{H}]^{-}, 1073$ [1543-146-162-162] $]^{-}$HRESIMS (pos. ion mode) $m / z 1567.7150[\mathrm{M}+\mathrm{Na}]^{+}$(calcd. for $\mathrm{C}_{71} \mathrm{H}_{116} \mathrm{NaO}_{36}, 1567.7144$ ).

\subsection{Acid Hydrolysis and GC Analysis of the Sugar Moieties in 1-5}

Compounds 1-5 (4 mg each) in $1 \mathrm{M} \mathrm{HCl}$ (dioxane- $\mathrm{H}_{2} \mathrm{O} 1: 1, v / v, 5 \mathrm{~mL}$ ) were heated at $95{ }^{\circ} \mathrm{C}$ for $6 \mathrm{~h}$, respectively. The reaction mixture was evaporated in vacuo and the residue was extracted three times with $\mathrm{CHCl}_{3}$. The aqueous phase was concentrated and dissolved in pyridine $(5 \mathrm{~mL})$ and 1-(trimethylsilyl)imidazole $(0.5 \mathrm{~mL})$ at room temperature for $30 \mathrm{~min}$. The reaction mixture was dried with a stream of $\mathrm{N}_{2}$. The residue was partitioned between $\mathrm{CHCl}_{3}$ and $\mathrm{H}_{2} \mathrm{O}$. The organic layer was subjected to GC analysis using an L-Chirasil-Val column. The sugar units were identified by comparing the retention times of the corresponding trimethylsilylated derivatives with those of the authentic samples prepared in the same manner [19]. Retention times for authentic samples after being derivatized were 9.12 and $10.05 \mathrm{~min}$ (D-arabinose), 9.30 and $10.29 \mathrm{~min}$ (L-arabinose), 9.90 and $10.69 \mathrm{~min}$ (D-rhamnose), 9.70 and $10.58 \mathrm{~min}$ (L-rhamnose), 11.15 and $12.36 \mathrm{~min}$ (D-xylose), 11.27 and $12.30 \mathrm{~min}$ (L-xylose), $14.95 \mathrm{~min}$ (D-glucose), and $15.18 \mathrm{~min}$ (L-glucose), respectively. L-Arabinose, L-rhamnose, D-xylose and D-glucose were identified in a ratio of 1:1:1:2 for 1, 1:2:1:3 for 2 and 1:2:1:4 for 3, while the sugar moieties of $\mathbf{4}$ and $\mathbf{5}$ were identified as L-arabinose, L-rhamnose and D-glucose in the ratio of 1:2:3 and $1: 2: 4$, respectively.

\subsection{Assays for in Vitro Antitumor Activity}

The cytotoxicity of compounds $\mathbf{1}-\mathbf{5}$ against human promyelocytic leukemia HL-60 cells, human hepatocellular carcinoma HepG2 cells, human lung carcinoma A549 cells and human cervical carcinoma HeLa cells (all four cancer cell lines were obtained from ATCC, Manassas, VA, USA) was evaluated by MTT colorimetric assay described in previous papers [31], with doxorubicin (Sigma-Aldrich, St. Louis, MO, USA) as positive control. Briefly, $4 \times 10^{3} / \mathrm{mL}$ cells were added to 96 -well plates (100 $\mu \mathrm{L} /$ well), and incubated with various concentrations of drugs $(80,40,20,10,5,1$ and $0.2 \mu \mathrm{M})$ in triplex wells for $48 \mathrm{~h}$ at $37{ }^{\circ} \mathrm{C}$ in a humidified $5 \% \mathrm{CO}_{2}$ atmosphere. After $48 \mathrm{~h}, 20 \mu \mathrm{L} 3-(4,5-$ dimethylthiazol-2-yl)-2,5-diphenyltetrazolium bromide (MTT) solved in PBS was added to each well at a concentration of $5 \mathrm{mg} / \mathrm{mL}$, and then incubated for another $4 \mathrm{~h}$. The water-insoluble dark blue formazan crystals formed during MTT cleavage in actively metabolizing cells were dissolved in DMSO. The optical density of each well was measured with a Bio-Rad 680 microplate reader (Bio-Rad, Hercules, CA, USA) at $570 \mathrm{~nm}$. Cytotoxicity was expressed as the concentration of drug inhibiting cell growth by $50 \%\left(\mathrm{IC}_{50}\right)$.

\section{Conclusions}

Phytochemical investigation of the rhizomes of $A$. rivularis var. flore-minore, led to the isolation of five new oleanane-type triterpenoid saponins 1-5 along with five known saponins 6-10. Their structures were elucidated on the basis of spectroscopic studies and chemical evidence. These compounds were based on three types of aglycones, i.e., gypsogenin, oleanolic acid and $21 \alpha$-hydroxyoleanolic 
acid, and the third type of aglycone was found from the Ranunculaceae family for the first time. All of the compounds were tested for cytotoxicity against HL-60, HepG2, A549 and HeLa cell lines. The monodesmosidic saponins 6-8 exhibited cytotoxic activity toward all cancer cell lines, with $\mathrm{IC}_{50}$ values in the $7.25-22.38 \mu \mathrm{M}$ range.

\section{Supplementary Materials}

Physical and spectroscopic data of compounds 6-10, along with NOESY and HMBC correlations for compounds $\mathbf{2} \mathbf{- 5}$ are available as supporting data, which can be accessed at: http://www.mdpi.com/ $1420-3049 / 19 / 2 / 2121 / \mathrm{s} 1$.

\section{Acknowledgments}

This work was financially supported by the National Natural Science Foundation of China (Nos. 30873402 and 81274029), the National Science and Technology Support Program of China (No. 2012BAK25B00) and the Administration of Traditional Chinese Medicine of Shaanxi Province, P.R. China (No. zy36).

\section{Conflicts of Interest}

The authors declare no conflict of interest.

\section{References}

1. National Pharmacopoeia Committee. Pharmacopoeia of People's Republic of China; Chemical Industry Press: Beijing, China, 2010; p. 157.

2. Ye, W.C.; Zhang, Q.W.; Zhao, S.X.; Che, C.T. Four new oleanane saponins from Anemone anhuiensis. Chem. Pharm. Bull. 2001, 49, 632-634.

3. Lu, J.C.; Xu, B.B.; Gao, S.; Fan, L.; Zhang, H.F.; Liu, R.X.; Kodama, H. Structure elucidation of two triterpenoid saponins from rhizome of Anemone raddeana. Regel. Fitoterapia 2009, 80, 345-348.

4. Wang, M.K.; Wu, F.E.; Chen, Y.Z. Triterpenoid saponins from Anemone hupehensis. Phytochemistry 1997, 44, 333-335.

5. Mimaki, Y.; Watanabe, K.; Matsuo, Y.; Sakagami, H. Triterpene glycosides from the tubers of Anemone coronaria. Chem. Pharm. Bull. 2009, 57, 724-729.

6. Sun, Y.X.; Liu, J.C.; Liu, D.Y. Phytochemicals and bioactivities of Anemone raddeana Regel: A review. Pharmazie 2011, 66, 813-821.

7. Zhang, L.T.; Zhang, Y.W.; Takaishi, Y.; Duan, H.Q. Antitumor triterpene saponins from Anemone flaccida. Chin. Chem. Lett. 2008, 19, 190-192.

8. Wang, J.L.; Liu, K.; Gong, W.Z.; Wang, Q.; Xu, D.T.; Liu, M.F.; Bi, K.L.; Song, Y.F. Anticancer, antioxidant, and antimicrobial activities of Anemone (Anemone cathayensis). Food Sci. Biotechenol. 2012, 21, 551-557.

9. Wang, J.R.; Ma, J.Q.; Peng, L.L.; Feng, J.T.; Ding, L.S. Chemical constituents and antifeeding activity of Anemone tomentosa. Acta Bot. Boreali. Occid. Sin. 1998, 18, 643-644. 
10. Flora of China Editorial Committee of Chinese Academy of Sciences. Flora of China; Science Press: Beijing, China, 1980; Volume 28, p. 24.

11. Ding, Y.; Tang, H.F.; Wang, J.B.; Liu, D.; Tian, X.R.; Wang, X.Y.; Zhou, X.M. Triterpenoid saponins from Anemone rivularis var. flore-minore. Biochem. Syst. Ecol. 2011, 39, 236-239.

12. Ding, Y.; Tian, X.R.; Tang, H.F.; Feng, J.T.; Zhang, W.; Hai, W.L.; Wang, X.Y.; Wang, Y. Two new glycosides from the whole plant of Anemone rivularis var. flore-minore. Phytochem. Lett. 2012, 5, 668-672.

13. Wang, Y.; Kang, W.; Hong, L.J.; Hai, W.L.; Wang, X.Y.; Tang, H.F.; Tian, X.R. Triterpenoid saponins from the root of Anemone tomentosa. J. Nat. Med. 2013, 67, 70-77.

14. Wang, X.Y.; Chen, X.L.; Tang, H.F.; Gao, H.; Tian, X.R.; Zhang, P.H. Cytotoxic triterpenoid saponins from the rhizomes of Anemone taipaiensis. Planta Med. 2011, 77, 1550-1554.

15. Wang, X.Y.; Zhang, W.; Gao, K.; Lu, Y.Y.; Tang, H.F.; Sun, X.L. Oleanane-type saponins from the rhizomes of Anemone taipaiensis and their cytotoxic activities. Fitoterapia 2013, 89, 224-230.

16. Wang, X.Y.; Gao, H.; Zhang, W.; Li, Y.; Cheng, G.; Sun, X.L.; Tang, H.F. Bioactive oleanane-type saponins from the rhizomes of Anemone taipaiensis. Bioorg. Med. Chem. Lett. 2013, 23, 5714-5720.

17. Nie, R.L.; Tanakaa, T.; Miyakoshia, M.; Kasaia, R.; Moritaa, T.; Zhou, J.; Tanaka, O. A triterpenoid saponin from Thladiantha hookeri var. pentadactyla. Phytochemistry 1989, 28, 1711-1715.

18. Mahato, S.B.; Kundu, A.P. ${ }^{13}$ C-NMR Spectra of pentacyclic triterpenoidse-A compilation and some salient features. Phytochemistry 1994, 37, 1517-1575.

19. De Marino, S.; Borbone, N.; Iorizzi, M.; Esposito, G.; McClintock, J.B.; Zollo, F. Bioactive asterosaponins from the starfish Luidia quinaria and Psilaster cassiope. Isolation and structure characterization by two-dimensional NMR spectroscopy. J. Nat. Prod. 2003, 66, 515-519.

20. Zheng, Q.; Koike, K.; Han, L.K.; Okuda, H.; Nikaido, T. New biologically active triterpenoid saponins from Scabiosatschiliensis. J. Nat. Prod. 2004, 67, 604-613.

21. Xu, T.H.; Xu, Y.J.; Li, H.X.; Han, D.; Zhao, H.F.; Xie, S.X.; Xu, D.M. Two new triterpenoid saponins from Pulsatillacernua (Thunb.) Bercht. etOpiz. J. Asian Nat. Prod. Res. 2007, 9, $705-711$.

22. Werner, S.; Nebojsa, S.; Robert, W.; Robert, S.; Olaf, K. Complete assignments of ${ }^{1} \mathrm{H}$ and ${ }^{13} \mathrm{C}$-NMR resonances of oleanolic acid, $18 \alpha$-oleanolic acid, ursolic acid and their 11-oxo derivatives. Magn. Reson. Chem. 2003, 41, 636-638.

23. Zhang, W.; Yao, M.N.; Tang, H.F.; Tian, X.R.; Wang, M.C.; Ji, L.J.; Xi, M.M. Triterpenoid saponins with anti-myocardial ischemia activity from the whole plants of Clematis tangutica. Planta Med. 2013, 79, 673-679.

24. Mimaki, Y.; Yokosuka, A.; Hamanaka, M.; Sakuma, C.; Yamori, T.; Sashida, Y. Triterpene saponins from the roots of Clematis chinensis. J. Nat. Prod. 2004, 67, 1511-1516.

25. Lavaud, C.; Crublet, M.L.; Pouny, I.; Litaudon, M.; Sdonet, T. Triterpeniod saponins from the stem bark of Elattostachys apetala. Phytochmistry 2001, 57, 469-478.

26. Zhang, Q.W.; Ye, W.C.; Che, C.T.; Zhao, S.X. Triterpene saponins from Pulsatilla cernua. Acta Pharm. Sin. 2000, 35, 756-759. 
27. Schenkel, E.P.; Werner, W.; Schulte, K.E. Saponins from Thinouia coriaceae. Planta Med. 1991, 57, 463-467.

28. Sawada, H.; Miyakoshi, M.; Isoda, S.; Ida, Y.; Shoji, J. Saponins from leaves of Acanthopanax sieboldianus. Phytochemistry 1993, 34, 1117-1121.

29. Bang, S.C.; Lee, J.H.; Song, G.Y.; Kim, D.H.; Yoon, M.Y.; Ahn, B.Z. Antitumor activity of Pulsatilla koreana saponins and their structure-activity relationship. Chem. Pharm. Bull. 2005, 53, 1451-1454.

30. Yokosuka, A.; Sano, T.; Hashimoto, K.; Sakagami, H.; Mimaki, Y. Triterpene glycosides from the whole plant of Anemone hupehensis var. japonica and their cytotoxic activity. Chem. Pharm. Bull. 2009, 57, 1425-1430.

31. Alley, M.C.; Scudiero, D.A.; Monks, A.; Hursey, M.L.; Czerwinski, M.J.; Fine, D.L.; Abbott, B.J.; Mayo, J.G.; Shoemaker, R.H.; Boyd, M.R. Feasibility of drug screening with panels of human tumor cell lines using a microculture tetrazolium assay. Cancer Res. 1988, 48, 589-601.

Sample Availability: Samples of the compounds 1-10 are available from the authors.

(C) 2014 by the authors; licensee MDPI, Basel, Switzerland. This article is an open access article distributed under the terms and conditions of the Creative Commons Attribution license (http://creativecommons.org/licenses/by/3.0/). 